\title{
Correlations of genetic resistance of chickens to Marek's disease viruses with vaccination protection and in vivo response to phytohemaglutinin
}

\author{
JS Gavora ${ }^{1}$, JL Spencer ${ }^{2}$, I Okada ${ }^{3}$, AA Grunder ${ }^{1}$ * \\ with the technical assistance of PS Griffin ${ }^{1}$, E. Sally ${ }^{2}$ \\ 1 Agriculture Canada, Animal Research Centre, Ottawa, Ontario, K1A OC6 \\ ${ }^{2}$ Agriculture Canada, Animal Diseases Research Institute, \\ Nepean, Ontario, Canada K2H $8 P 9$ \\ 3 Faculty of Applied Biological Science, Hiroshima University, Department of \\ Animal Science, Higashi-Hiroshima, Japan
}

(Received 6 December 1989; accepted 17 September 1990)

Summary - Twenty-three genetic groups of experimental and commercial meat and egg chickens were injected with moderately virulent BC-1 (exp 1) or highly virulent RB-1B (exp 2) Marek's disease (MD) virus. Birds of 7 genetic groups were divided into vaccinated and non-vaccinated groups and exposed by contact to the virulent RB-1B virus in exp 3 . Response to phytohemaglutinin (PHA) injected in wing webs was measured in adult birds of all 23 groups (exp 4) to assess its relationship to MD resistance. There was a high correlation $(0.8)$ between resistance of the genetic groups to the two viruses indicating that selection for resistance to one virus would be expected to improve resistance to the other virus. Regression of MD incidence in vaccinated birds on that in non-vaccinated birds resulted in regression coefficients of $0.41,0.23$, and $0.31 \%$ for males, females and combined sexes respectively, indicating that MD incidence increased linearly in vaccinated birds in relation to their genetic susceptibility to MD. Two significant correlations in males suggested that high swelling response to PHA may under some conditions be associated with MD resistance. However, the correlation coefficients were inconsistent and it was concluded that swelling response to PHA inoculated in the wing web is not predictive of MD resistance.

chicken / Marek's disease / vaccination / phytohemaglutinin

Résumé - Corrélations entre la résistance génétique de poulets aux virus de la maladie de Marek, la protection de la vaccination et la réaction in vivo à la phytohémagglutinine. Vingt-trois types génétiques de poulets, représentant des souches "chair» et "ponte» expérimentales et commerciales, ont été inoculés avec deux virus de la Maladie de Marek: le virus BC-1, modérément virulement (expérience 1) et le virus

* Animal Research Centre Contribution No 1652 
$R B-1 B$, fortement virulent (expérience 2). Les sujets de sept types génétiques ont été repartis en groupes vaccinés et non vaccinés et ont été exposés par contact au virus virulent $R B-1 B$ dans l'expérience 3. La réaction à la phytohémagglutinine (PHA) injectée dans les membranes alaires a été mesurée chez des sujets adultes des 23 types génétiques (expérience 4) pour évaluer sa liaison avec la résistance à la maladie de Mareck. On constate une forte corrélation (0.8) entre la résistance des types génétiques aux deux virus, ce qui montre que la sélection pour la résistance à un virus semble améliorer la résistance à l'autre virus. La régression de la fréquence de la maladie de Marek chez les sujets vaccinés sur celle des sujets non vaccinés est de 0.41 ; $0.23 ; 0.31 \%$ pour les mâles, les femelles et les deux sexes combinés respectivement, indiquant par là que, chez les sujets vaccinés, la fréquence de la maladie de Marek augmente de façon linéaire avec les sensibilités génétique à la maladie de Marek. Deux corrélations significatives à l'injection de PHA peut, dans certains conditions, être liée à la résistance à la maladie de Marek. Cependant, les coefficients de corrélation sont contradictoires et les auteurs concluent que la réaction de gonflement consécutive à l'inoculation de PHA dans la membrane alaire ne peut servir à prédire la résistance à la maladie de Marek.

poulet / maladie de Marek / vaccination / phytohémagglutinine

\section{INTRODUCTION}

Marek's disease (MD) is caused by a herpes virus that induces neoplastic transformation of host T-cells, resulting in formation of lymphoid tumors. Protection by vaccines is not complete and the combination of both vaccination and genetic resistance is required for optimum protection (Spencer et al, 1972, Gavora and Spencer, 1979). Appearance of very virulent strains of MD virus associated with increased MD losses in vaccinated flocks (Witter, 1988) emphasizes the need to improve vaccines and to increase levels of genetic resistance.

In this context, questions of practical importance are (1) whether genotypes resistant to moderately virulent $\mathrm{MD}$ viruses are also resistant to highly virulent viruses, and (2) what is the degree of protection by vaccination against the virulent viruses in genotypes that differ in their natural MD resistance. Genetic improvement of resistance can be accomplished by direct selection based on response to $\mathrm{MD}$ virus or, more desirably, on marker traits measurable without exposure to the pathogen. Response of chickens to phytohemaglutinin (PHA) was considered a potential marker trait for this purpose.

$T$-cells play a dual role in the pathogenesis of $\mathrm{MD}$, in that they are both the target cells for neoplastic transformation, and act with natural killer cells, in defence against MD tumors (Sharma et al, 1977, Sharma, 1981). Susceptibility to MD tumors may be linked to strong cell-mediated immune response and is influenced by both age and genotype of the bird (Calneck, 1986) and MD resistance is, at least partly, the property of the target T-cells (Gallatin and Longenecker, 1979).

Response of chickens to PHA injected intradermally is a measure of cell-mediated immunity involving T-cells (Goto et al, 1978), although the response is cellularly heterogeneous (Edelman et al, 1986). Response of chickens to PHA differs among commercial stocks (Van der Zijpp, 1983), or experimental lines (Lamont and Smyth, 1984) and is influenced by both sex and major histocompatibility haplotype (Taylor et al, 1987). 
The relationship of PHA response and MD resistance is not clearly understood. A line of chickens selected for high plasma corticosterone had an impaired in vitro response of lymphocytes to PHA and greater $\mathrm{MD}$ tumor incidence and mortality than a low corticosterone line (Thompson et al, 1980). In contrast, Lee and Bacon (1983) reported that increased in vitro response of lymphocytes to phytohemaglutinin was associated with increased susceptibility to MD. However, Calnek et al (1989) dit not observe any general correlation between the responses of multiple genetic groups of chickens to mitogens Concavalin A and PHA or mixed lymphocyte reaction, and MD susceptibility.

In this study, correlations between resistance of several genetic groups of chickens to two strains of MD virus that differed widely in virulence were investigated and the relationship between genetic resistance to $M D$ and protection by vaccination was assessed. The relationship of genetic resistance to $\mathrm{MD}$ with swelling response induced by the injection of PHA into the wing web is also reported.

\section{MATERIALS AND METHODS}

\section{Chickens}

A description of the genetic groups used in the study is given in table I and the populations used are shown in figure 1 . The parental populations were reared

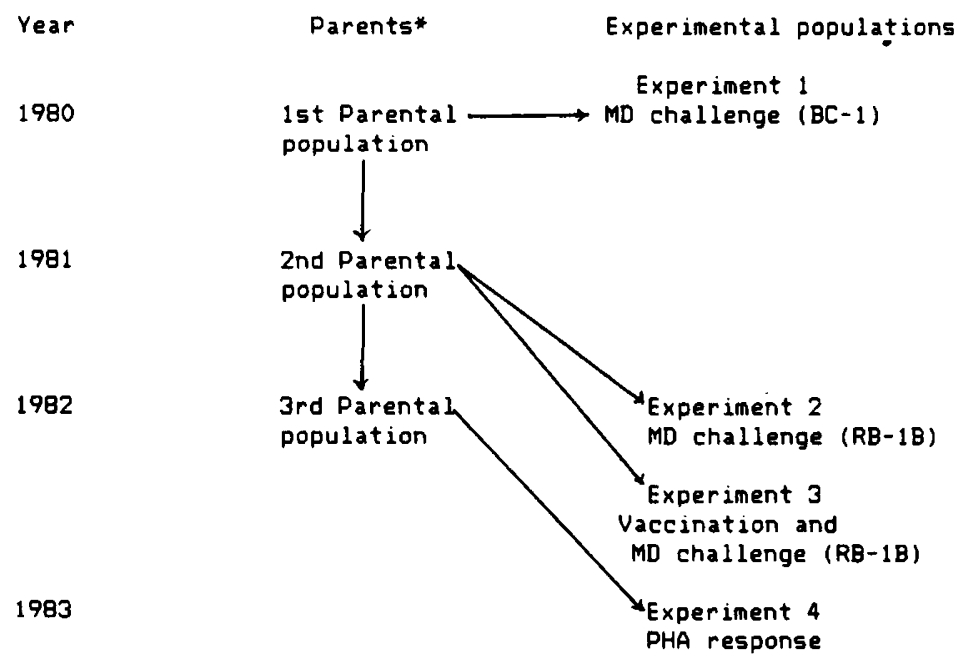

Fig 1. Relationships among the populations used in the study.

* 10 sires and 50 dams randomly selected per each outbred genetic group (table I) and 5 sires and 25 dams each per inbred line were used to produce the experimental birds. The genetic groups were reproduced in the same way except for strains $5,7,10,2 R, 3 R$, and $8 \mathrm{R}$ that were pedigreed and each sire was represented in the next generation mating by a son, and each dam by a daughter. In strains $2 R, 3 R$ and $8 R, 50$ sires and 100 dams were reproduced in this manner. 
Table I. Description of the genetic groups used in the study.

\begin{tabular}{lll}
\hline Genetic & Description & References \\
Group & & \\
Code & & \\
\hline
\end{tabular}

White Leghorns:

A Commercial layer stock.

5 Narrow genetic base control strain maintained unselected in Ottawa since 1950

Gowe and Fairfull (1980)

1 Derived from strain 5 in 1950. Selected for high egg production and related economically important traits

Gowe and Fairfull (1980)

3R Developed from Ottawa strains 1 and 3, by inbreeding and selection for Marek's disease resistance, high egg production and related economically important traits

Gavora (1979)

$7 \quad$ Broad genetic base control strain synthesized in 1958, maintained since unselected

Gowe and Fairfull (1980)

8 Derived from strain 7 in 1969 and selected since for high egg number and related economically important traits

Gowe and Fairfull (1980)

8R Same as 3R, developed from Ottawa strains $8 \& 9$

Gavora (1979)

Gavora et al (1986)

$2 \quad$ Synthesized in 1951 and selected since for high egg production rate and related economically important traits

Gowe and Fairfull (1980)

10 Broad genetic base control strain synthesized in 1973, maintained since unselected

Gowe and Fairfull (1980)

2R Same as 3R, developed from Ottawa strains $2 \& 4$

Gavora (1979)

CS Selected for susceptibility to Marek's disease at Cornell University until 1971. Maintained since at Ottawa unselected

Hutt and Cole (1957)

Gavora et al (1979)

CK Same as CS but selection was for Marek's disease resistance, high egg production, and egg weight

Hutt and Cole (1957)

XP02 Inbred sub line of line XP, derived form Ottawa steain 9 , homozygous for major histocompatibility haplotype $B^{2}$

Gavora and Spencer (1979)

XP21 Same as XP02, homozygous for $B^{21}$

Gavora and Spencer (1979)

GH inbred line derived from strain 3, susceptible to Marek's disease

Gavora et al (1982)

GF Inbred line derived from strain 3, resistant to Marek's disease

Gavora et al (1982) 
Table I' (cont'd)

\begin{tabular}{lll}
\hline Genetic & Description & References \\
Group & & \\
Code & \\
\hline
\end{tabular}

Brown egg-producing, medium sized birds:

B Commercial layer stock

NH Randombred New Hampshire stock Grunder et al (1972)

Meat-type birds:

C Commercial broiler stock

KK Unselected control strain maintained at Ottawa since 1955

Chambers et al (1981)

AA Derived from $\mathrm{KK}$ in 1958 , selected for high broiler weight for 14 generations, maintained since in Ottawa unselected

Chambers et al (1981)

20 Synthesized in 1979 from commercial broiler sire stocks, maintained since in Ottawa unselected

Chambers et al (1984)

30 Same as 20, for commercial dam stocks

Chambers et al (1984)

intermingled in floor pens and housed in individual cages as adults. They were vaccinated for $\mathrm{MD}$, infectious bronchitis and Newcastle disease, as well as avian encephalomyelitis, and were fed mash rations throughout their lifetime. They were given a uniform light diet in all generations. No major disease outbreak was experienced in any of the parental flocks or the 1983 flock used for the PHA test. In all these flocks, rearing mortality was less than $8 \%$ and laying house mortality less than $10 \%$. In addition to the above parents, parallel specific pathogen-free (SPF) parent populations for genetic groups $\mathrm{CS}, \mathrm{CK}$, and $\mathrm{NH}$ were maintained on a filtered-air, positive-pressure building where they received no vaccines and were free of Marek's disease virus and other avian pathogens.

\section{Marek's disease challenge tests (exp 1, 2 and 3)}

For the MD challenge tests the birds were in floor pens in an isolation facility (Grunder et al, 1972). At 3 weeks of age, each bird was inoculated intraperitoneally with the respective $\mathrm{MD}$ virus isolant. In $\exp 1$, the inoculum contained the $\mathrm{BC}-1$ virus (Spencer et al, 1972) and the birds produced from both conventionally housed and SPF parents were observed for $63 \mathrm{~d}$ after inoculation. In exp 2 the inoculum was the RB-1B virus (Schat et al, 1981) and the duration was $56 \mathrm{~d}$ after inoculation. The inocula for both experiments were from lots of cell-associated virus stored in liquid nitrogen that had previously been tested for pathogenicity.

Exp 3 included 130 to 147 birds from each of 7 genetic groups (A,3R,7,8,8R,CS, and $\mathrm{CK}$ ). Approximately half of these birds were vaccinated on the day of hatch with 6000 plaque-forming units of cell-associated herpes virus of turkeys. The birds 
were kept in isolation until $14 \mathrm{~d}$ of age and were then exposed to seeder birds previously infected with the RB-1B virus. The birds were killed at $53 \mathrm{~d}$ after the exposure.

All birds that died or were killed because of illness, and survivors that were killed at termination of the tests, were necropsied. MD incidence was based on gross lesions.

\section{Phytohemaglutinin (PHA) response test (Exp 4)}

The dose and inoculation site for this experiment was determined on the basis of a preliminary test using 30 adult White Leghorn females and 12 adult White Leghorn males inoculated with 75,500 and $1250 \mathrm{mg}$ of PHA per bird in the wattle or wingweb. Wing webs were found easier to measure as wattles tended to be soft and pliable. Of the doses tested, 500 and $1250 \mathrm{mg}$ gave similar swelling responses in the wing web.

The procedure used in exp 4 was similar to that of Van der Zijpp (1983). Adult birds (482 d of age at PHA inoculation) were each inoculated intradermally with $0.125 \mathrm{ml}$ of phosphate buffered saline (PBS) in the left wing web. The same volume of PBS containing $500 \mathrm{mg} \mathrm{PHA}{ }^{*}$ was inoculated in the right wing web. Prior to the inoculation the wing webs were plucked free of feathers and the inoculation sites, close to but not on the edge of the web were marked with a felt pen.

Thickness of the wing web was measured before inoculation, as well as 24 and $48 \mathrm{~h}$ after inoculation, using Miluyo electronic micrometer, model No 293-701 that applied constant pressure on all wing webs, independent of the operator. The swelling index (I) was calculated as

$$
I=\left(T_{R 2}-T_{R 1}\right)-\left(T_{L 2}-T_{L 1}\right),
$$

where " $T$ " is the thickness and subscripts " $R$ " and " $\mathrm{"} \mathrm{indicate} \mathrm{the} \mathrm{right} \mathrm{and}$ left wing web and " 1 " and "2" indicate thickness before and after inoculation, respectively.

\section{Statistical analyses}

Spearman's rank and Pearson's product-moment correlation between resistance to the BC-1 and RB-1B viruses and PHA response were calculated on the basis of genetic group means. The dependence of MD incidence in vaccinated birds on MD incidence in non-vaccinated birds was assessed by linear regression using genetic group means. $\mathrm{MD}$ incidence among genetic groups and vaccination treatments was compared by homogeneity $\chi^{2}$ tests and differences between grouping of genetic groups by the student's $t$-test. Individual bird swelling index data after PHA challenge were subjected to analysis of variance using a model containing the effects of genetic group, sex and their interaction.

\footnotetext{
${ }^{*}$ Lot No 721460, Difco, Ltd
} 


\section{RESULTS}

\section{Resistance to the $B C-1$ and $R B-1 B$ isolants of $M D$ virus}

MD incidence after challenge with the BC-1 and the RB-1B isolants of MD virus differed widely in exp 1 and 2 (table II). In exp 1, the overall MD incidence induced by $\mathrm{BC}-1$ was close to $15 \%$ and this was significantly lower $(P<0.01)$ than the $47 \%$ MD incidence induced by RB-1B in exp 2 .

The ranges of $\mathrm{MD}$ incidence among the genetic groups tested were from 0 to $46.4 \%$ in males and 0 to $89.7 \%$ in females in exp 1 , and from 5.7 to $93.7 \%$ in males and from 4.1 to $97.2 \%$ in females in exp 2. In genetic groups 8R, XP02, and XP21 there was no incidence of MD after BC-1 challenge while MD was observed in all genetic groups after challenge with RB-1B (table II). Among the birds challenged with BC-1 there was a significant sex difference $(P<0.05)$, the incidence being $11.5 \%$ higher in females than in males. The corresponding sex difference of $4.2 \%$ in birds challenged with RB-1B was not statistically significant. With the exception of strain NH females, MD incidence in strains CS, CK, and NH in exp 1 was not significantly different between birds produced from conventionally and SPF housed dams.

The relationship between resistance of the genetic groups to the BC-1 and RB1B challenge was expressed in terms of Spearman's rank and Pearson's productmoment correlations (table III). the correlations for males and females separately, as well as for sexes combined were all high and significant, although correlations tended to be higher in females.

\section{Relationship of genetic resistance to $M D$ and vaccination protection}

Incidence of Marek's disease in the non-vaccinated birds exposed by contact to RB-1B in exp 3 at 2 weeks of age (fig 2) was in good agreement with that in the same genetic groups challenged by injection at 3 weeks of age in exp 2 (table II), although the average MD incidence in contact challenge was $6.6 \%$ lower. Vaccination conferred significant protection $(P<0.05)$ to both males and females and there were high and significant correlations between MD incidence in the vaccinated and non vaccinated birds (table III).

Linear regressions were fitted for the relationship between $M D$ incidence in nonvaccinated birds. The regression accounted for 92,68 and $95 \%$ of total variation $\left(R^{2}\right)$ for males, females and sexes combined. The respective regression coefficients were $0.41,0.23$, and 0.31 for males, females and sexes combined. Thus, in this experiment, MD incidence in vaccinated birds increased linearly with their genetic susceptibility (fig 2) and a combination of genetic resistance with vaccination resulted in the best protection.

\section{Marek's disease resistance and response to phytohemaglutinin}

The means of the swelling index measured at $24 \mathrm{~h}$ after injection with PHA are shown in table II. The mean swelling at $48 \mathrm{~h}$ post injection and the differences between the $48 \mathrm{~h}$ and $24 \mathrm{~h}$ swelling were also calculated but are not shown in the table. Although the time of peak response was not determined, the $24 \mathrm{~h}$ response 





Table III. Correlations between resistance to injection challenge with Marek's disease (MD) isolants BC-1 and RB-1B and between MD incidence in vaccinated and non vaccinated chickens exposed by contact to RB-1B. All correlations in the table were significant $(P<0.01)$.

\begin{tabular}{lccc}
\hline & & \multicolumn{2}{c}{ Correlation type } \\
\cline { 3 - 4 }$M D$ incidence & Sex & $S^{1}$ & $P^{2}$ \\
\hline BC-1 vs RB-1B & $\mathrm{M}$ & 0.56 & 0.63 \\
(exp 1 and 2) & $\mathrm{F}$ & 0.76 & 0.81 \\
& Combined & 0.83 & 0.85 \\
Non-vaccinated $v s$ vaccinated & $\mathrm{M}$ & 1.00 & 0.98 \\
(exp 3) & $\mathrm{F}$ & 0.89 & 0.94 \\
& Combined & 0.96 & 0.98 \\
\hline
\end{tabular}

${ }^{1}$ Spearman's rank correlation. ${ }^{2}$ Pearson's product-moment correlation of arcsine $\%$.

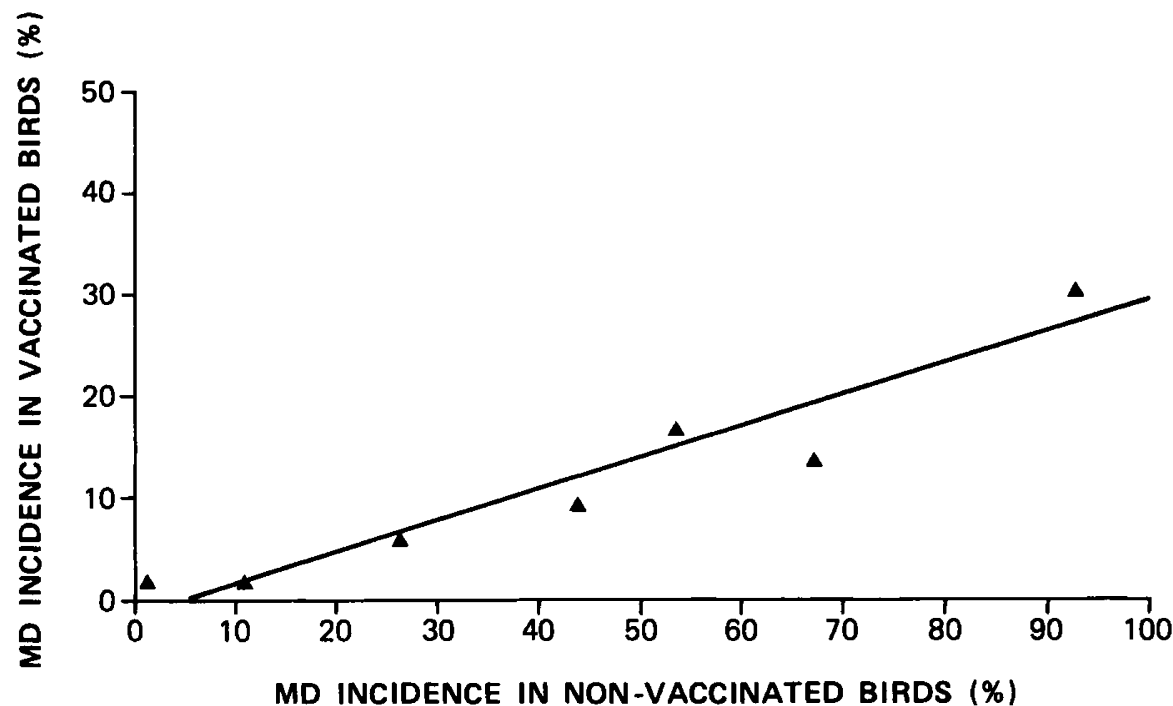

Fig 2. Relationship of genetic resistance to Marek's disease and vaccination protection in seven genetic groups of chickens exposed to the virulent MD virus RB-1B. Data from sexes combined.

was, as a rule, greater than that of $48 \mathrm{~h}$. There were highly significant differences among the genetic groups and sexes and genetic group by sex interaction was also significant for the $24 \mathrm{~h}$ index (table IV). The mean swelling at $24 \mathrm{~h}$ was larger in males than in females. Nevertheless, in 5 out of the 23 groups, females showed a greater swelling than males - hence the significant interaction. For the swelling index measured at $48 \mathrm{~h}$, the overall effect of sex was no longer significant but the effect of genetic group and its interaction with sex reached statistical significance. In 
comparisons between sexes, the greater swelling was in males in 11 genetic groups and in females in 12 genetic groups. The tendency was for swelling to develop more slowly and to peak later in females than in males.

Table IV. Analysis of variance of the phytohemaglutinin response (swelling index in mm).

\begin{tabular}{lrll}
\hline & & \multicolumn{2}{c}{ Mean squares } \\
Source of variation & $D f$ & \multicolumn{2}{c}{ Swelling index at } \\
\hline Genetic group (GG) & 22 & $0.616^{* *}$ & $48 h$ \\
Sex & 1 & $5.375^{* *}$ & $0.549^{* *}$ \\
GG $\times$ sex & 22 & $0.412^{*}$ & 0.019 \\
Residual & 429 & 0.228 & 0.213 \\
\hline
\end{tabular}

${ }^{*} P \leq 0.05 ;{ }^{* *} P \leq 0.01$

Table V. Spearman's rank (S) and Pearson's (P) product-moment correlations between Marek's disease (MD) incidence and response to phytohemaglutinin in 23 genetic groups of chickens.

\begin{tabular}{lccccc}
\hline $\begin{array}{l}\text { Virus isolant } \\
\text { used for } \\
\text { challenge }\end{array}$ & & \multicolumn{4}{c}{$\begin{array}{c}\text { Time post-challenge when phytohemaglutinin } \\
\text { response was measured }\end{array}$} \\
\cline { 2 - 6 } & & \multicolumn{3}{c}{$24 h$} & \multicolumn{2}{c}{$48 h$} \\
& $S e x$ & $S$ & $P^{1}$ & $S$ & $P^{1}$ \\
\hline BC-1 & $\mathrm{M}$ & -0.28 & -0.14 & $-0.42^{*}$ & -0.21 \\
& $\mathrm{~F}$ & -0.26 & -0.17 & -0.02 & 0.02 \\
& Combined & -0.38 & -0.24 & -0.19 & -0.13 \\
RB-1B & $\mathrm{M}$ & -0.33 & -0.24 & $-0.37^{*}$ & -0.23 \\
& $\mathrm{~F}$ & 0.06 & 0.06 & 0.34 & 0.31 \\
& Combined & -0.22 & -0.15 & -0.02 & 0.03 \\
\hline
\end{tabular}

${ }^{1}$ For the calculation of Pearson's correlations, arcsin $\%$ MD incidence was used. ${ }^{*} P \leq 0.05$

Rank-order and product-moment correlations of MD incidence and wing web swelling after PHA inoculation are shown in table V. Only the negative correlations of the $48 \mathrm{~h}$ swelling index of males with MD resistance reached statistical significance. The remaining correlations of $24 \mathrm{~h}$ and $48 \mathrm{~h}$ swelling indices for males were also negative, while those for females were inconsistent in both sign and magnitude.

\section{DISCUSSION}

Incidence of Marek's disease among the genetic groups in both exp 1 and 2 varied widely and in exp 2 spanned almost the entire range from 0 to $100 \%$ (table II). The incidence of MD lesions was described in more detail by Spencer et al (1984) 
showing that the predominant lesion in BC-1 inoculated females was in the ovary and in males in nerves. The RB-1B virus induced a high proportion of visceral lesions in both males and females. As observed previously (Grunder et al, 1972), BC-1 induced a higher incidence of MD in females than males. No significant sex difference was observed in MD incidence after RB-1B challenge. This, together with the large difference between the overall MD incidences after BC-1 and RB1B challenge, emphazises the genetic divergence between the two virus strains. The correlations between resistance to the MD viruses (table III), as well as that between this resistance and PHA (table V), express genetic relationships because the correlations are based on means of the genetic groups, which are themselves genetic characteristics.

Since there were high correlations between resistance to BC-1 and RB-1B, selection for resistance to one of the viruses would also be expected to improve resistance to the other. This conclusion was supported by comparisons of related genetic groups that have undergone various degrees of selection. There were 3 such sets of genetics groups of Leghorns, each originating from a different genetic base population (table I). The sets consisted each of a strain selected for high egg production, egg weight and related economically important traits including viability (P-strains), and of strains selected for resistance to the BC-1 virus in addition to the above traits (R-strains). Selection for resistance to the BC-1 significantly $(P \leq 0.01)$ improved resistance of the $\mathrm{R}$-strains $3 \mathrm{R}$ and the $8 \mathrm{R}$ to the $\mathrm{RB}-1 \mathrm{~B}$ virus compared with their respective $P$-strain counterpart strains 1 and 8 (table II). In the third set, there was no significant difference between the $P$-strain 2 and $R$-strain $2 R$ in $\mathrm{RB}-1 \mathrm{~B}$ resistance.

Our results from lines XP02 and XP21 confirm the resistance of the $B^{21}$ haplotype (XP21) and $B^{2}$ haplotype (XP02) against multiple MD viral strains (Gavora et al, 1986; Bacon 1987). The commercial stocks differed widely in MD resistance: Leghorn stock A was among the most resistant group, however, stocks $\mathrm{B}$ and $\mathrm{C}$ were far more susceptible (table II).

The linear relationship between genetic resistance to MD and protection by vaccination (fig 2) was based on only 7 genetic groups but should have a broad validity for the virus strain and vaccine type tested, as the resistance of the nonvaccinated groups practically spanned 0 to $100 \%$. The positive correlatinn between resistance to the RB-1B and BC-1 isolants of MD virus suggest that the relationship of MD resistance and protection by vaccination may also be valid for other MD viruses.

In the determination of the PHA swelling index, possible differences in wing web thickness of the right and left wing or the variation in the response to PBS were not considered as it was shown that they are negligible (Van der Zijpp, 1983). Overall, the levels of response to PHA in this study were lower than those observed by Van der Zijpp (1983) and Lamont and Smyth (1984). This discrepancy may be due to the lower dose of PHA and older age of the birds in this study, as well as the genotypes of birds tested. Similar to the present study, Van der Zijpp (1983), Lamont and Smyth (1984), as well as Goto et al (1978) used conventionally housed birds for the PHA inoculation experiments.

The correlations of MD incidence with PHA response (table V) were generally low and inconsistent. The two correlations that were significantly different from 
zero, as well as the sign of 7 out of the 8 correlations for sexes combined in the table, suggested a tendency for the high PHA response to be associated with MD resistance. Consistent with the observations of Thompson et al (1980), this would indicate that the bird's ability to mount a cell-mediated immune response is important for MD resistance.

Of the three sets of R- and P-strains, described, for combined sexes, the Rstrains $2 R$ and $3 R$ had greater PHA response than the corresponding P-strains 2 and 1 (table II). The reverse was observed for the third set of R-strains $8 \mathrm{R}$ and P-strains 8. In addition most of the correlations between PHA response and MD resistance were non significant (table V). Therefore, in agreement with Calnek et al (1989), who studied in vitro PHA response of lymphocytes from strains of varying resistance to $\mathrm{MD}$, we conclude that swelling response to PHA inoculation in the wing web is not sufficiently predictive of MD resistance to justify its use in genetic selection.

\section{REFERENCES}

Bacon LD (1987) Influence of the major histocompatibility complex on disease resistance and productivity. Poultry Sci 66, 802-811

Calnek, BW (1986) Marek's disease: A model for herpes virus oncology. CRC Crit Rev Microbiol 12, 293-320

Calnek BW, Adene DF, Schat KA (1989) Immune responsiveness versus susceptibility to Marek's disease. Poultry Sci 68, 17-26

Clanek BW, Schat KA, Heller ED, Buscaglia C (1984) In vitro infection of T-lymphocytes with Marek's disease virus In: Proceedings of the International Symposium on Marek's Disease (Calnek BW, Spencer JL, ed) Am Assoc of Avian Pathol Kennett Square, PA, 347-358

Chambers JR, Bernon DE, Gavora JS (1984) Synthesis and parameters of new populations of meat type chickens. Theor Appl Genet 69, 23-30

Chambers JR, Gavora JS, Fortin A (1981) Genetic changes in meat type chickens in the last twenty years. Can J Anim Sci 61, 555-563

Edelman AS, Sanchez DL, Robinson ME, Hochwald GM, Thorbecke GJ (1986) Primary and secondary wattle swelling response to phytohemaglutinin as a measure of immunocompetence in chickens. Avian Dis 30, 105-111

Gallatin WM, Longenecker BM (1979) Expression of genetic resistance to an oncogenic herpes virus at the target cell level. Nature 280, 587-589

Gavora JS (1979) Genetic techniques for controlling Marek's disease and for improvement of multiple traits in high performance egg production chickens. 29th Anim Breeders' Roundtable, Menphis, Tennessee, 33-58

Gavora JS, Emsley A, Cole RK (1979) Inbreeding in 35 generations of development of Cornell S Strain of Leghorns. Poultry Sci 58, 1133-1136

Gavora JS, Longenecker BM, Spencer JL, Grunder AA (1982) New histocompatibility haplotypes and Marek's disease in chickens. 2nd World's Poultry Congress on Genetics Applied to Livestock Production. Vol 7, 351-361

Gavora JS, Spencer JL (1979) Studies on genetic resistance of chickens to Marek's disease - a review. Comp Immun of Microbiol Infect Dis 2, 359-371 
Gavora JS, Simonsen M, Spencer JJ, Fairfull WR, Gowe RS (1986) Changes in the frequency of major histocompatibility haplotypes in chickens under selection for both high egg production and resistance to Marek's disease. $Z$ Tierz Zuchtungsbiol $103,218-226$

Goto N, Kodama H, Okada K, Fijimoto Y (1978) Suppression of phytohemaglutinin skin response in thymectomized chickens. Poultry Sci 57, 246-250

Gowe RS, Fairfull RW (1980) Performance of six long-term multitrait selected Leghorns strains and three control strains and strains cross evaluation of the selected strains. Proc 1980 South Pacific Poult Sci Convention, Auckland, NZ 141162

Grunder AA, Jeffers TK, Spencer JL, Robertson A, Speckmann G (1972) Resistance of strains of chickens to Marek's disease. Can J Anim Sci 52, 1-10

Hutt FB, Cole RK (1957) Control of leukosis in the fowl. J Am Vet Med Assoc 131, 491-495

Lamont SJ, Smyth JR Jr (1984) Effect of selection for delayed amelanosis on immune response in chickens. 2. Cell mediated immunity. Poultry Sci 63, 440-442

Lee FL, Bacon LD (1983) Ontogeny and line differences in the mitogenic response of chicken lymphocytes. Poultry Sci 62, 579-584

Schat KA, Calnek BW, Fabricant J (1981) Influence of oncogenicity of Marek's disease virus on evaluation of genetic resistance. Poultry Sci 60, 2559-2566

Sharma JM (1981) Natural killer cell activity in chickens exposed to Marek's disease virus: inhibition of activity in suscpetible chickens and enhancement of activity in resistant and vaccinated chickens. Avian Disease 25, 882-893

Sharma JM, Nazerian K, Witter RL (1977) Reduced incidence of Marek's disease gross lymphomas in T-cell depleted chickens. $J$ Natl Cancer Inst 59, 1-5

Spencer JL, Gavora JS, Chen SS, Shapiro JL (1984) Factors influencing resistance and distribution of lesions in chickens exposed to BC-1 and RB-1B isolates of Marek's disease virus. In: Proceedings of the International Symposium on Marek's Disease, (Calnek EW, Spencer JL eds) Am Assoc of Avian Pathol, Kennett Square, PA 359-371

Spencer JL, Grunder AA, Robertson A, Speckmann GW (1972) Attenuated Marek's disease herpes virus: protection conferred on strains varying in genetic resistance. Avian Dis 16, 94-107

Taylor RL Jr, Cotter PF, Wing TL, Briles WE (1987) Major histocompatibility ( $B$ ) complex and sex effects on the phytohemaglutinin wattle response. Anim Genet 18, 343-350

Thompson DL, Elgert KD, Gross WB, Siegel PB (1980) Cell mediated immunity in Marek's disease virus-infected chickens genetically selected for high and low concentrations of plasma corticosterone. Am J Vet Res 41, 91-96

Van der Zijpp AJ (1983) The effect of genetic origin, source of antigen and dose of antigen on the immune response of cockerels. Poultry Sci 62, 205-211

Witter RL (1988) Very virulent Marek's disease viruses: Importance and control. Proceedings XVIII World's Poultry Congress, Nagoya, Japan, 92-98 